\title{
THE COST OF LIVING IN THE UNITED STATES 1914-1927
}

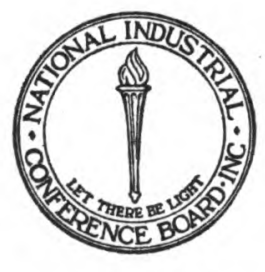

NATIONAL INDUSTRIAL CONFERENCE BOARD, INC. NEW YORK

1928 